Proc. Indian Acad. Sci. (Chem. Sci.), Vol. 90, Number 3, June 1981, pp. 237-241.

(C) Printed in India.

\title{
Mixed-ligand complexes of copper VII. Polarographic studies on copper-carboxylate-aminocarboxylate complexes
}

\author{
V V RAMANUJAM* and U KRISHNAN \\ Department of Inorganic Chemistry, A.C. College Buildings, Madras 600025 , \\ India \\ MS received 12 November 1980; revised 11 March 1981

\begin{abstract}
The formation constants of mixed-ligand complexes with hetero donors of the type CuAB where $A$ is a carboxylic acid such as lactic acid or oxalic acid and $B$ is an $\alpha$ - or $\beta$-amino acid are studied by polarography. The mixed-ligand stabilisation constant clearly indicates the preferred formation of copper(II) mixedligand complexes with hetero donors over homo donors. The other driving forces leading to the favoured formation of mixed-ligand complexes are also discussed.
\end{abstract}

Keywords. Mixed-ligand complexes; copper(II); lactic acid; oxalic acid; amino acid.

\section{Intraduction}

The polarographic method widely used to study single-ligand systems, has however been rarely applied to mixed-ligand complexes. It was first used for the study of mixed-ligand complexes by Schaap and McMasters (1961) by extending the method of DeFord and Hume (1951) to determine the consecutive overall formation constants of single-ligand complexes. Recently Sigel (1975) and Krishnan (1980) have reiterated that copper(II) prefers hetero donors over homodonors in mixed-ligand complexes. The results obtained from the polarographic technique for some of the mixed-ligand complexes of copper(II) with biologically important bidentate ligands with hetero donor atoms are presented in this paper.

\section{Experimental}

\subsection{Copper-oxalate-aminocarboxylate complexes}

2.1a. Effect of $p H$. Polarograms were recorded for solutions containing a constant concentration of copper(II) $\left(3.98 \times 10^{-4} \mathrm{M}\right)$ and a varying large excess of oxalate and/or aminocarboxylate. At $\mathrm{pH}$ values near 5 the dioxalatocuprate (II) is the predominant species present and at $\mathrm{pH}$ above 8 only diglycinatocopper (II) is present. In the intermediate $\mathrm{pH}$ range of $5 \cdot 4-6 \cdot 8$, both mixed-ligand complexes and binary complexes are present as inferred from the magnitude of

\footnotetext{
* To whom all correspondence should be made.
} 
the $\Delta E_{1 / 3}$. This is in accordance with the findings from our spectrophotometric studies Ramanujam and Krishnan (1980) where $\lambda_{\max }$ is the deciding factor. The plot of $E_{1 / 2}$ vs $\mathrm{pH}$ in the $\mathrm{pH}$ range of $5 \cdot 4-6.8$ is linear as seen from figure 1 and the slope of these are about $0.03 \mathrm{~V}$, showing the involvement of one proton in the electrode process. This would protonate the $-\mathrm{NH}_{2}$ group of the aminocarboxylate ion. The electrode process may be represented as follows :

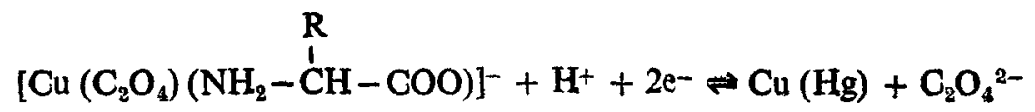<smiles>[R]C([NH3+])C(=O)[O-]</smiles>

2.1b. Effect of ligand concentration on $E_{1 / 2}$. To determine the formula of the mixed-ligand complex the method of Lingane (1941) used for the binary complexes was modified. Keeping the $\mathrm{pH}$ constant (at the preselected value) and the concentration of one of the ligands (say, secondary ligand) was varied. From the plot of $E_{1 / 2}$ vs - $\log$ [secondary ligand], the value of the slope $P$, gives the number of secondary ligands coordinated to $1: 1$ coppar(II)-primary ligand complex.

As it is experimentally much easier to hold the oxalate concentration constant and vary the aminocarboxylate concentration, than vice versa, the $E_{1 / 2} v s-\log$ [secondary ligand] plot is constructed with respect to the aminocarboxylate ion

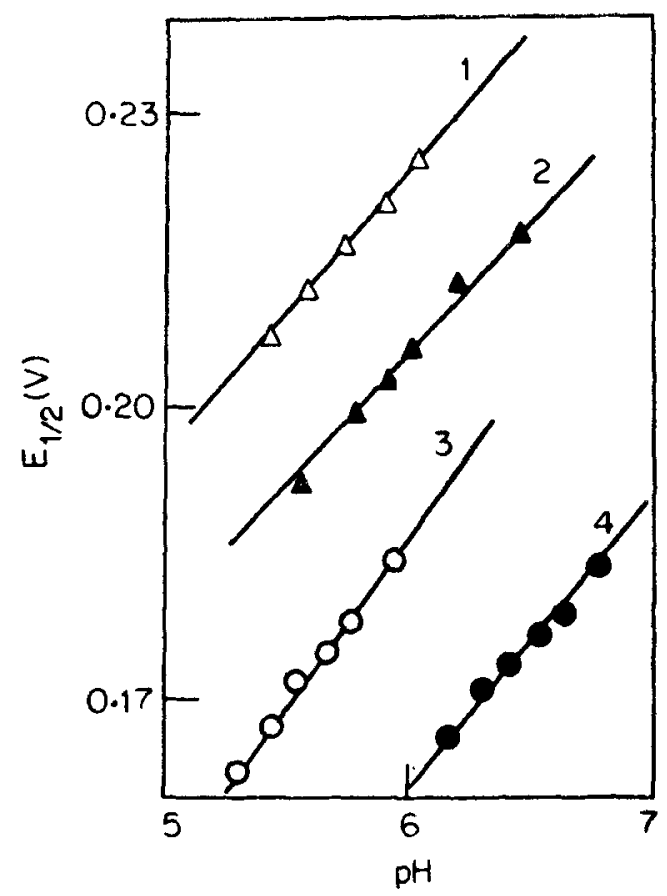

Figure 1. Copper-oxalate-aminlocarboxylate complexes. Plot of $E_{\mathbf{j}}$ vs $\mathrm{pH}$ 1. [Cu (ox) (gly)]. 2. [Cu (ox) (ala)]. 3. [Cu (ox) (ser)]. 4. [Cu (ox) (bala)]. 
concentration. As a representative system such a curve for $[\mathrm{Cu}$ (ox) (gly)]* at $\mathrm{pH} 5.85$ and a constant oxalate concentration of $0.110 \mathrm{M}$ is shown in figure 2 . The slope of this plot is 0.028 corresponding to $P=1$, indicating clearly that only one glycinate group is added to the $1: 1$ copper-oxalate complex. The same formula was arrived at by Ramanujam and Krishnan (1980) from spectrophotometric studies.

The formation constants obtained for all the mixed-ligand complexes by the method of Schaap and McMasters (1961) are found to be fairly constant over the $\mathrm{pH}$ range at which linear curves are obtained for the $E_{1 / 2}$ vs $\mathrm{pH}$ plot (figure 1). The values obtained closely agree with those obtained from spectrophotometric studies as can be seen from table 1 .

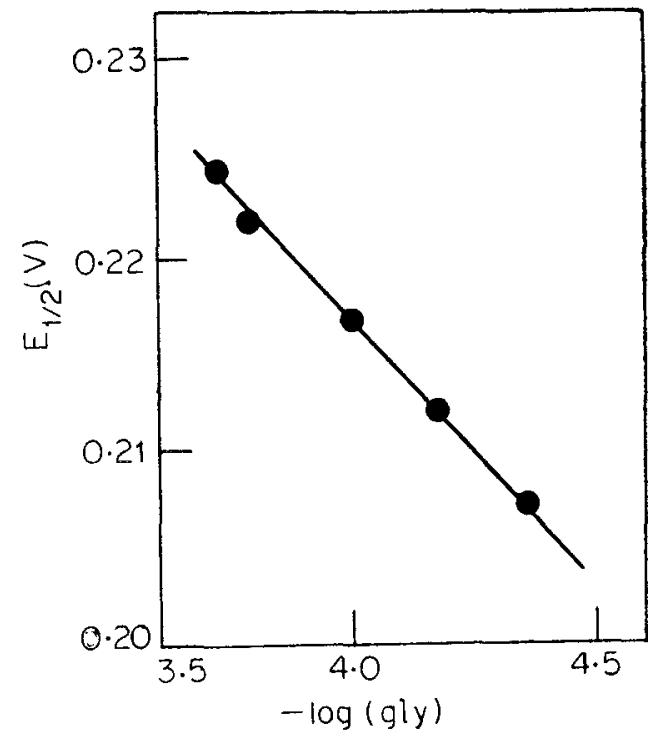

Figure 2. Copper-oxalate-glycinate complex. Effect of glycinate concentration on $E_{3}$ at $\mathrm{pH}=5.85$ and $o x=0.110 \mathrm{M}$.

Table 1. Copper-oxalate-aminocarboxylate complexes.

\begin{tabular}{|c|c|c|c|}
\hline & Polarography & & SFectrophotometry* \\
\hline Complex & $\log \beta$ & $\log X$ & $\log \beta$ \\
\hline $\begin{array}{l}{[\mathrm{Cu}(\mathrm{ox})(\mathrm{gly})]} \\
{[\mathrm{Cu}(\mathrm{ox})(\mathrm{ala})]} \\
{[\mathrm{Cu}(\mathrm{ox}) \text { (ser)] }} \\
{[\mathrm{Cu}(\mathrm{ox}) \text { (bala) }]}\end{array}$ & $\begin{array}{r}12.93 \pm 0.06 \\
12.79 \pm 0.05 \\
12.06 \pm 0.06 \\
11.87 \pm 0.04\end{array}$ & $\begin{array}{l}1 \cdot 48 \\
1 \cdot 29 \\
0 \cdot 90 \\
1 \cdot 84\end{array}$ & $\begin{array}{l}12 \cdot 90 \pm 0.05 \\
12 \cdot 67 \pm 0.18 \\
12 \cdot 08 \pm 0.03 \\
11 \cdot 72 \pm 0.16\end{array}$ \\
\hline
\end{tabular}

* Values of $\log \beta$ from Ramanujam and Krishnan (1980).

* Abbreviations: ala $=a$-alaninate; $a m=$ aminocarboxylate; $b a l a=\beta$-alaninate; en $=$ ethylenediamine; $g l y=$ glycinate; fact - lactate; $a x=$ oxalate; $p n=1,3$-propylenediamine and ser $=$ serinate. 
The mixed-ligand stabilization constant, $\log X$ is calculated from the disproportionation reaction such as shown below :

$$
\begin{aligned}
& {\left[\mathrm{Cu}(\mathrm{ox})_{2}\right]+\left[\mathrm{Cu}(\mathrm{am})_{2}\right] \rightleftharpoons[2 \mathrm{Cu}(\mathrm{ox})(\mathrm{am})]} \\
& X=\frac{[\mathrm{Cu}(\mathrm{ox})(\mathrm{am})]^{2}}{\left[\mathrm{Cu}(\mathrm{ox})_{2}\right]\left[\mathrm{Cu}(\mathrm{am})_{2}\right]} \\
& \log X=2 \log \beta_{\mathrm{cu}(\mathrm{ox})(\mathrm{am})}-\left\{\log \beta_{\mathrm{cu}(\mathrm{ox})_{2}}+\log \beta_{\mathrm{cu}(\mathrm{sm})_{2}}\right\} .
\end{aligned}
$$

The $\log X$ value proposed by Sharma and Schubert (1969) on statistical grounds is 0.6 and an observed value of $\log X$ greater than 0.6 indicates favoured forma. tion of the mixed-ligand complexes over binary complexes. The high $\log X$ values listed in table 1 show that the mixed-ligand complexes are highly favoured.

The variation of $E_{1 / 2}$ with $\mathrm{pH}$ was studied for the mixed-ligand complexes of copper(II) with lactate and aminocarboxylate in the $\mathrm{pH}$ range 5.2-6.4 as described earlier for the [Cu (ax)(am)] systems. Linear plots are obtained with a slope of about $0.03 \mathrm{~V}$. This value corresponds to one proton which is inferred to protonate the $-\mathrm{NH}_{2}$ group of the aminocarboxylate ion as shown below :
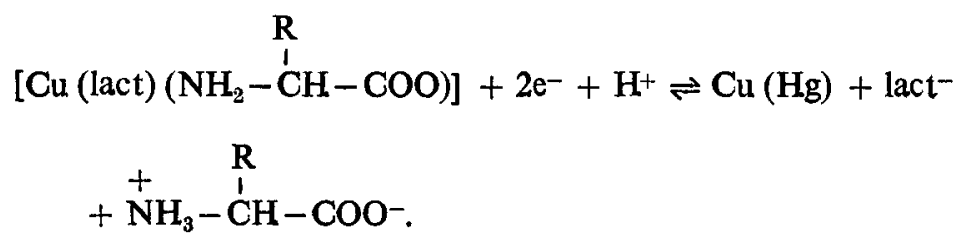

Studies on the effect of varying the aminocarboxylate ion concentration on $E_{1 / 2}$ at $\mathrm{pH} 5.60$ and at a lactate ion concentration of $0.25 \mathrm{M}$ showed the composition of the mixed-ligand complex to be [Cu (lact) (am)].

The overall formation constant of these mixed-ligand complexes calculated over the $\mathrm{pH}$ range of $5 \cdot 2-6 \cdot 4$ is fairly constant. The values obtained here are in good agiement with those of $\mathrm{pH}$-metric and spectrophotometric studies as can be seen from table 2. The $\log X$ values for all these complexes are seen to be high. The preference for mixed-ligand complexes with one five- and one sixmembered ring over two five-membered rings is clearly brought out in all cases where $\beta$-alanine is one of the ligands and forms a six-membered ring.

The $\log X$ value among the $\alpha$-amino acids varies in the order glycinate $>\alpha$ alaninate $>$ serinate. This trend may be due to steric factors, namely, the presence of more substituent groups in the chelating ligands.

The $\log X$ values of these mixed-ligand complexes where three donor sites are oxygen atoms and one is a nitrogen atom are higher than those having only oxygen or nitrogen as donors. The $\log X$ values of some mixed-ligand complexes of copper(II) with homo and hetero donor atoms calculated from polarographic data are listed in table 3.

In the case of [Cu (lact) (am)] the complex is neutral. The formation of a neutral complex appears to be a strong driving force for the favoured formation of the mixed-ligand complexes. This is one of the reasons for the enhanced value of $\log X$ for $[\mathrm{Cu}(\mathrm{lact})(\mathrm{am})]$ compared to $[\mathrm{Cu}(\mathrm{ox})(\mathrm{am})]$ with a uninegative charge. 
Table 2. Copper-lactate-aminocarboxylate complexes.

\begin{tabular}{lcccc}
\hline & $\begin{array}{c}\text { Polarography } \\
\log \beta\end{array}$ & $\log X$ & $\begin{array}{c}\text { pH-metry @ } \\
\log \beta\end{array}$ & $\begin{array}{c}\text { Spectrophotometry @ } \\
\log \beta\end{array}$ \\
\hline Complex & $10.83 \pm 0.04$ & 2.51 & $10.91 \pm 0.02$ & $10.74 \pm 0.06$ \\
{$[$ Cu (lact) (gly)] } & $10.70 \pm 0.05$ & 1.66 & $10.65 \pm 0.14$ & $10.22 \pm 0.07$ \\
{$[$ Cu (lact) (ala)] } & $10.09 \pm 0.03$ & 1.67 & $10.02 \pm 0.07$ & $9.76 \pm 0.07$ \\
{$[$ Cu (lact) (ser)] } & $9.74 \pm 0.06$ & 2.81 & $9.97 \pm 0.11$ & $9.68 \pm 0.08$ \\
{$[C u$ (lact) (bala)] } & & & & \\
\hline
\end{tabular}

(a) Values of $\log \beta$ from Krishnan (1980).

Table 3. I $\circ$ og $X$ values of some of the mixed-ligand complexes of copper(II) with homo and hetero donors from Krishnan (1980).

\begin{tabular}{lccc}
\hline \multicolumn{4}{c}{ Donors } \\
Complex & Oxygen & Nitrogen & $\log X$ \\
& & & \\
\hline$[\mathrm{Cu}(\mathrm{lact})(\mathrm{ox})]$ & 4 & 0 & $0 \cdot 43$ \\
{$\left[\mathrm{Cu}(\mathrm{ox})\left(g^{\prime} y\right)\right]$} & 3 & 1 & $1 \cdot 48$ \\
{$[\mathrm{Cu}(\mathrm{lact})(\mathrm{en})]$} & 2 & 2 & $2 \cdot 62$ \\
{$[\mathrm{Cu}(\mathrm{en})(\mathrm{gly})]$} & 1 & 3 & $1 \cdot 71$ \\
{$[\mathrm{Cu}(\mathrm{en})(\mathrm{pn})]$} & 0 & 4 & $1 \cdot 17$ \\
\hline
\end{tabular}

In the case of lactate complexes, the studies indicate coordination of the hydroxyl group in its unionised form. Martin and Paris (1963) and Griesser et al (1968) have also indicated the participation of the hydroxyl group in coordination in mixed-ligand complexes. Such a coordination is weaker than in its deprotonated form. It is of great importance in biological processes such as metal-enzyme action, as it allows a rapid rearrangement of the complexes necessary for the enzyme to act as a catalyst.

\section{References}

DeFord D D and Hume D N 1951 J. Am. Chem. Soc. 735321

Griesser R, Prijs B and Sigel H 1968 Inorg. Nucl. Chem. Lett. 4443

Krishnan U 1980 Pt.D. Thesis, Studies on mixed ligand complexes of copper (II) Universtiy of Madras

Lingane J J 1941 Chem. Rev. 291

Martin R P and Paris R A 1963 Bull. Soc. Chim. France 1600

Ramanujam V V and Krishnan U 1980 Indian J. Chem. 19A 779

Schaap W B and McMasters D L 1961 J. Am. Chem. Soc. 834699

Sharma V S and Schubert J 1969 J. Chem. Edn. 46506

Sigel H 1975 Angew. Chem. Int. Edn. 14394 